\title{
The Challenges of Muslim Countries in Business World
}

\author{
Rafidah Binti Haji Amidon \& Amal Norhaizah \\ Student of Master Muamalat Administration (MMA), \\ Universiti Sains Islam Malaysia, Nilai, Negeri Sembilan, 78100. \\ E-mail:amal@gmail.com
}

\begin{abstract}
Throughout the centuries, the Muslim countries has evolved and branched out to the world of arts, literature, philosophy, technology, economy, law and ethics, education, even politics inclusive of its conflict. Most of what occurred throughout the centuries was documented and used as reference in future studies such as studied done in medical by Ibnu Sina. Many part of the world have form negative perspectives of the Muslim countries especially by correlating negative incidents occurred in some part of the world as practice of all Muslim in the Muslim countries. Living in the Muslim countries has its advantages and disadvantages in which it will be discussed further in this essay. from the discussion below, it can be conclude that any world no matter the religion, the belief, the political standing is bombarded with dilemmas of identifying the advantages and disadvantages of their world to face the challenges of globalization. Distinguishing the advantages or the disadvantages without implicating neither sense of pride or sense of shame has been the practice that is being encouraged by all. The most important impression that the Muslim world can make is through the beauty of tolerance, understanding and the concept of sharing without judging others.
\end{abstract}

Keywords: business world, Muslim countries, advantages and disadvantages.

\section{Introduction}

The terms "Muslim world" or known to some as "Ummah" or "Islamophere" has been defined through three different perspectives, in the sense of religious, cultural as well as geopolitical sense. Through the sense of religious, one has to grasp from the root the meaning of the word "Muslim". Literary "Muslim" is defined as "one who submit", by which it means one who submit to Allah, believing in Him and obeying HIS commandments. As for the cultural sense, it is more on civilization, including the non-Muslim living in that civilization whereas 
for geopolitical sense it is being referred collectively to Muslim majority countries, states, districts or towns, for example the Arab Peninsula is considered as part of the Muslim world. Throughout the centuries, the Muslim countries has evolved and branched out to the world of arts, literature, philosophy, technology, economy, law and ethics, education, even politics inclusive of its conflict. Most of what occurred throughout the centuries was documented and used as reference in future studies such as studied done in medical by Ibnu Sina. The scholars have proven that the Muslim countries are also rich and diverse with knowledge that is beneficial not just for them but for the whole world. As the modernization of the world begins part of those which is considered as Muslim countries also evolved however not without any disadvantages. Issues arise from all corner of the world that challenges the basis by which the Muslim world has been developed, challenging the faith as it grows. Many part of the world have form negative perspectives of the Muslim countries especially by correlating negative incidents occurred in some part of the world as practice of all Muslim in the Muslim countries. Living in the Muslim countries has its advantages and disadvantages in which it will be discussed further in this essay.

\section{Globalization and its Challenges in Business World}

The distance that once take years to arrive can be shortened to just several hours, communications are becoming easier every day, advanced technologies are continuously invented to make people's life easier. Business nowadays can be done easily all across the world. This process of increasing connectivity and interdependence of the world ${ }^{\text {ee }} \mathrm{s}$ markets and businesses is called globalization. In today's world it is relevant to ask do Muslim countries also affected by the globalization? The answer is yes. In fact, there are a lot of challenges due to the globalization which have to be faced by Muslim countries. As the globalization picks up its speed, there is no doubt that Muslim countries have some disadvantages in order to cope with the global challenges in the business world. Global culture tends to homogenize societies along the lines of a Western model that does not always fit well with local culture. Islamic countries are no exception.

Muslim countries are among those communities which are faced with critical challenges in term of how to adjust with new global flows and modernity. Some of the challenges are: (1) Global poverty and inequality, (2) an issue of terrorism, (3) Natural resources. (4) Communication and technology, (5) Promotion of global harmony and integration. Global challenges in business world are a controversy debate and significant matter for all nations. This subject like many other issues has some advantages and disadvantages towards Muslim countries. In this paper, both of positive sides and negative points of being a Muslim country in facing these challenges will be elaborated.

\section{Problems of Muslim Countries}

\subsection{Poverty and Inequality}


The first challenge as mentioned earlier is poverty and inequality. The term poverty is used to describe the non-existence of food, shelter, money and clothing that occurs when people cannot satisfy their basic needs. It can be understood simply as a lack of money or more broadly in terms of barriers to everyday life. In most nations today, poverty and inequality - the gap between the rich and the poor - exist and the scale is quite high and often widening. This is mostly caused by capitalism which has ruled the world over 100 years ago. Capitalism which only favored the rich and ignored the poor created the unpleasant environment where the well-off rich people get richer and the poor people just get poorer. Average 25,000 people die every day of hunger or hunger-related causes, according to the United Nation. Almost half of the world - over 3 billion people lives on less than $\$ 2.50$ a day. There are about 1 billion children live in poverty, 640 million live without adequate shelter, 400 million have no access to safe water and about 270 million people have no access to health services. According to the World's Bank classification, there is a bulk of Islamic countries that fall into the category of low-income countries (LIC) with income of $\$ 975$ or less and Lower-middle income countries (LMC) with income ranging between $\$ 976$ and $\$ 3855$. Poverty is even higher in Muslim countries compared to other countries. In World Development Report 2009, most of Muslim countries are in the stage of developing. There is a lack of independent scientific and technological research in these countries and they are reliant on foreign aid or capital. Most Muslim countries are dependent on the West for technological infrastructure (machinery, equipment, medicine, etc.) and high quality consumer and luxury goods. Liberalization of technological diffusion and innovation guarantees that Muslim countries will be permanently dependent on the West which is seen negatively by the "Dependency school of thought". To face this challenge, actually Muslim countries are at advantage in avoiding this situation from becoming more severe. This is because Islam is a generous religion. It teaches people to understand each other"s difficulties, so that there will always be justice among people and the welfare of others is not forgotten. It encourages people to help each other so people can live in peace and harmony.

Islam has a very unique redistribution system called zakat and sadaqah. Zakat is one of five pillars of Islam. Every well-off Muslim is obliged to pay zakat based on clear-cut criteria, it is also known as 'an obligatory charity' expected from every Muslim. Shariah law has made it clear in defining the nature of who are liable to pay zakat and who can benefit from zakat. The first and foremost category of potential beneficiaries is the poor and the destitute. Sadaqah is a voluntary act of giving alms to the needy people by Muslims who want to contribute more than just the obligatory zakat payment. Both zakat and sadaqah is instrument of charity that occupies a central position in the Islamic scheme of poverty alleviation. The main objective of zakat payment and sadaqah is to prevent the hoarding of wealth and advocates solidarity among Muslims because excessive wealth is distributed among the poor. While Islam strongly encourages charity from the giver's point of view, it seeks to minimize dependence on charity from the beneficiary's point of view and restricts the benefits to flow to the poorest of poor and the destitute, which are not in a position to generate any income and wealth. By implementing zakat and sadaqah system, poverty and inequality that exist in Muslim countries can be reduced. The encouragement to 
help each other has also been mentioned in the Holy Quran (Surah Al-Maidah[5]: 2).

\subsection{Natural Resources}

One of the main factors for economic development is natural resources. The great majority of Muslim countries possess great geo-strategic advantages alongside valuable energy resources natural resources, especially natural gas and crude oil. The Gulf of Basra alone contains two-thirds of the world oil reserves discovered to date. Research has shown that Saudi Arabia by itself has reserves totaling 262 billion barrels, or $25.4 \%$ of the world total. Iraq possesses a further $11 \%$ of the world's oil reserves, the United Arab Emirates 9.6\%, Kuwait 9.2\%, Iran $8.6 \%$, other OPEC countries $13 \%$ and the rest of the world $22.6 \%$. Moreover, research by the U.S. Department of Energy shows that petrol exports from the Gulf will raise by $125 \%$ between 2000 and 2020. This means that a large proportion of the world's future energy needs will be met from the Gulf, just as they are today. It must also not be forgotten that in addition to petrol the Middle East contains $40 \%$ or so of the world's gas reserves, $35 \%$ of which lies in the Gulf. As known that the Persian Gulf holds two-third of the planet"s discovered crude oil reserves.

Moreover, Algeria, Libya and other North African countries possess $3.7 \%$ of the world's reserves. The Caucasus and Central Asian republics are also rich in natural gas and oil. The level of oil determined in Kazakhstan, for instance, stands at 10-17.6 billion barrels. Its natural gas capacity has been put at 53-83 trillion cubic meters. There are estimated to be 98-155 trillion cubic meters in the natural gas beds of Turkmenistan, which is the world's fourth largest natural gas producer. Some Muslim countries have very valuable mineral deposits. Uzbekistan and Kyrgyzstan, for example, are some of the world's major gold producers. Turkey possesses some of the world's largest boron reserves, the importance of which has become clearer in recent years. Tajikistan has the world's largest aluminum processing plants. Roughly, half of the petrol consumed in the west is exported from the Islamic countries. Many economists and strategists admit that the world economy depends upon the Islamic world's oil and gas exports, in particular those of the Persian Gulf. Because of the natural resources, Islamic countries have been able to stand at par with those of western countries. World Bank even classified some of Islamic countries as 'high income' countries.

In terms of natural resources, although most Muslim countries have strategic location in the world map as well as rich natural resources, these resources and strategic opportunities, however, are not being used effectively. The Islamic world is unable to take proper advantage posed by the territories it encompasses. Most countries, even those with rich natural resources, lack sufficient infrastructure and technological means to increase production or use the resources unearthed in their industries. The only contribution those resources make to a country's economy is in terms of exports. These countries lack the means to process and use oil in their own industrial complexes and to develop their own industries. Moreover, some Muslim countries even lack the means with which to carry out underground exploration and to locate and bring out the reserves identified.This advantage enjoyed by Muslim countries will become even more important in the $21^{\text {st }}$ century, referred to by some as the century of energy. In terms of industry, 
communications, urbanization and military matters, energy is one of the basic building blocks of modern society. Energy is essential for production and economic activity.

\subsection{Communication and Technology}

Globalization which is said to bring harmony and integration needs cooperation from all nations of the world. Because the absence of such cooperative atmosphere may lead to a clash of civilization which would be bad for everyone, particularly for the developing countries that do not possess the means of mass destruction that might serve as deterrence. The use of modern technology in business world nowadays is spreading rapidly. Gadgets like smart phones, computers, internet, tablet PCs are some of the inventions of modern technology. The medium of communication like letters and telegraphs are no longer relevant in this century. It is important to have a basic knowledge of using computers and internet today, as information is just a click away. There are a lot of advantages for Muslim countries that can be gained from these modern technologies, especially from the economic perspective. As distance can be shortened, business deals can be done just by sitting in the office or at home. Internet can connect people from all over the world. It opens opportunities to not only the businessmen to do business easily but also to commoners to start up business in the simplest way. This automatically helps the economy of the country and also reduces some of the social problem like unemployment. Instead of waiting for a job interview, the young generations can easily start their business online where large capital is not needed.

Social network services also play important roles in business world today. People use social network services like facebook as a medium of business transactions. Muslim countries should take advantages from the use of internet to help the economic growth as business done online is not only restricted to local but also international. The internetes impact is even greater for Muslim women, as they can have their own job now (doing online business) while taking care of their families and housework. They can also avoid the workplace problems like the discrimination of wearing hijab or veils. Apart from helping the country's economic development, Muslims can also make use of these modern technologies to spread Islamic knowledge and share it with other people all across the world. The speed of sharing knowledge online is undeniably faster than publishing it in the newspapers or books. Therefore, Muslim countries should utilize the advantages of the modern technology so that they will not be left behind and collect as much ideas and information as they can from the creation of the westerners.

\subsection{The Absence of Global Harmony and Integration}

The advantage for Muslim countries in realizing the goal of harmonization is that the idea is not something new to Muslim society. The Islamic teaching has always been about the unity. Unity of mankind is an essential corollary of the fundamental Islamic concept of the Unity of God (Tawhid). If God is one, then mankind is also one. The distinctions created by nationality, race and color are artificial and have no place in a religion, which stands for human brotherhood. 
The Qur'an clearly states that people were created as one nation (ummah) but became divided because of their differences. (Surah Yunus[10]:19). Conflicts of interest, prejudices, exploitation and misuse of power have taken their toll in dividing mankind. However, the ultimate objective of Islam is to reunite all of them. Muslim societies in Muslim countries are already exposed towards the importance of justice, fair play and cooperation among each other. The preparation to globalization has been done a long time ago in the Muslim countries. This is because Islam clearly indicates that efforts to bring about such integration are not likely to succeed if there is an absence of justice and fairness in human interaction. Hence, one of the major purposes of all Messengers sent by God to this world was to give mankind the necessary values or rules of behavior. These rules indicate how the people should interact with each other in this world so that there is justice, fair play, cooperation and solidarity among different nations, different groups of people, and all members of the family. It can be seen that justice is implemented in the business world of Islam. The prohibition of interest is the example of it. The interest is prohibit because a party involved in the interest-based contract gains money without taking any risk while the other party is exposed to the risk alone. With the prohibition, the rights of everyone in dealing business are protected. The risk of conflicts between people is minimized, and this is a little step that should be taken into the world of globalization.

Honesty and trust are also important in Islam. These two elements are the key to a successful business. According to the 2009 CPI (Corruption Perception Index), it showed that most Islamic countries, for example Qatar ranked 22, Brunei and Oman were rank 39 and Malaysia ranked 56, are less corrupt than the fastest growing emerging economies like China which was rank 79.

\subsection{Problem of Business' Area}

Another problem for Muslim countries in this competitive world is that the area for business operations is limited because some of the ideas might contradict with the Islamic teaching and thoughts, especially in the entertainment industry, for example music, fashion, movies, casinos, etc. In some of the developed countries, entertainment businesses bring a lot of fortune for the economic growth, while in Islam, this kind of things are prohibited which obviously left Muslim countries behind. Some of the Muslim countries are still holding on to the traditional Islamic belief that forbids women from working. This can be a disadvantage for the Muslim countries, because the future is almost certainly going to involve more technology, not less. No society can be well-equipped for this future if half of its members are only (at best) grudgingly given their rights. In some Islamic countries, women are often illiterate and have no rights in essential, critical life decisions, such as those involving child-rearing, marriage or education. According to CIA ${ }^{\text {ee }}$ S World Factbook, Pakistan is one of the poorest countries ranking $171^{\text {st }}$ in the world on the GDP per capita measure. Terror attacks are common in the country, and even Pakistan "e former Prime Minister Benazir Bhutto was killed as a result of a suicide attack in 2007. This brings a negative impact on the national economy of Pakistan.

\section{Concluding Remarks}


Any world no matter the religion, the belief, the political standing is bombarded with dilemmas of identifying the advantages and disadvantages of their world to face the challenges of globalization. Distinguishing the advantages or the disadvantages without implicating neither sense of pride or sense of shame has been the practice that is being encouraged by all. The most important impression that the Muslim world can make is through the beauty of tolerance, understanding and the concept of sharing without judging others. As stated in the introduction, the definition of the word "Muslim world" within the cultural sense is defined as civilization inclusive of the non-Muslim living in that civilization. This clearly depicts the appreciation towards the sense of diversity. Negative impression as well as perspectives grows because of what occurred in far region of countries that practices the same religion of those in the non - violent Muslim world. It is not easy to eradicate these types of perspectives however it is also not impossible to educate people. The core belief of any Muslim world will brought forth by the faith they have of Islam.

\section{Daftar Pustaka}

Chapra, M. Umer, (2001), Islamic Economic Thought and the New Global Economy, Islamic Economic Studies, Vol. 9, No.1. (2005), Global Economic Challenges and Islam, Institute of Policy Studies in Islamabad.

Grigorev, L. \& Salikhov, (2009), "Financial Crisis 2008; In Problems of Economic Transition, Vol. 51, No. 10.

Khan, Habibullah \& Omar KMR Bashar, (2010), The Impact of Globalization on Islamic Countries: A Brief Assessment, U21 Global Working paper series, No. 001.

Obaidullah, Mohammed, Islam, Poverty and Micro Finance "Best Practices", http://www.imad.in/obaidullah-micro1.pdf

Rapoport, A. \& Gerts, (2010), "The Global Economic Crisis of 2008-2009”, Problems of Economic Transition", Vol. 53.

Segal, Aaron, (1996), Why Does Muslim World Lag in Science?, Middle East Quarterly.

Yahya, Harun (Adnan Oktar), (2010), A Call for a Turkish-Islamic Union, The Benefits of Turkish-Islamic Union for Muslims, Second Edition,

Global Publishing, http://fs.fmanager.net/files/flashpages/index.php?bookid=2676 